\title{
Prohepcidin and Hepcidin in Acute Phase Reaction Accompanying Large Cardiac Surgery
}

\author{
Pavel Maruna, Martin Vokurka and Jaroslav Lindner \\ Charles University, \\ ${ }^{1}$ Faculty of Medicine, Institute of Pathological Physiology, \\ ${ }^{2}$ Department of Surgery - Department of Cardiovascular Surgery, Prague, \\ Czech Republic
}

\section{Introduction}

Hepcidin, a small cystein-rech peptide produced by the liver, was first described as an antimicrobial peptide (hepatic bactericidal protein) (Park et al. 2001) and subsequently discovered as a key regulator of iron homeostasis. Via regulation of ferroportin, hepcidin inhibits intestinal iron absorption and iron release from macrophages and hepatocytes (Ganz, 2006; Papanikolaou et al., 2005).

Hepcidin levels are regulated by at least three independent mechanisms (Nicolas et al., 2002). Whereas both inflammation and iron loading induce hepcidin production, erythropoietic activity suppresses its production. Apart from those factors also endoplasmic reticulum stress can induce hepcidin expression (Vecchi et al., 2009). In general, the decrease of hepcidin due to the iron deficiency or enhanced erythropoiesis stimulates iron intestinal absorption. On the other hand, iron-stimulated hepcidin production prevents iron overload. Increase in hepcidin concentration due to inflammation is considered important for iron sequestration (Ganz \& Nemeth, 2009). Studies of humans with severe inflammatory diseases have shown increased levels of hepcidin, suggesting that elevated hepcidin levels play a role in the anemia of inflammation (Nemeth et al., 2004; Krijt et al., 2009). Due to dominant regulation by interleukin-6 (IL-6), hepcidin was classified as a type II acute-phase protein (Nemeth et al., 2003). Increased IL-6 levels cause the binding of signal transducer and activator of transcription 3 (STAT3) to the hepcidin promoter, increasing its activity (Wrighting \& Andrews, 2006). Moreover, hepcidin itself has the potential to bind bivalent metal ions (Tselepis et al., 2010) and to mediate transcriptional changes of a wide variety of genes which can play important role in inflammatory response (De Domenico et al., 2010). That is why hepcidin can be considered as important inflammatory mediator, and its measurement can be helpful in many clinical situations. Technical problems prevented reliable and routine measurements of active 25 amino acid (aa) hepcidin in plasma until 2009. Therefore there are only limited data on hepcidin in human subjects, and much of findings come from animal and in vitro models.

To evaluate the time course of plasma hepcidin and its precursor prohepcidin in relation to inflammatory parameters, authors used a specific group of patients undergoing large cardiac surgery - pulmonary endarterectomy (PEA) in a deep hypothermic circulatory arrest 
(DHCA). PEA is a potential curative treatment method for patients with chronic thromboembolic pulmonary hypertension (CTEPH). PEA provides a significant survival advantage, compared to the natural prognosis of CTEPH (Roscoe \& Klein, 2008). The kinetics of main pro-inflammatory cytokines after PEA were described by Lindner et al. (2009) and Maruna et al. (2011) showing the relations of cytokine network to hemodynamic disturbances post-surgery. PEA leads to a more pronounced activation of cytokines than other surgical procedures (Langer et al., 2004; Martínes-Rosaz, 2006; Maruna et al., 2008 and 2009) with subsequent development of the systemic inflammatory response syndrome. Authors postulated that post-surgery changes of plasma hepcidin and its precursor would be responding to dynamics of other acute-phase proteins and related to IL-6 or other main inflammatory cytokines development.

\section{Material and methods}

\subsection{Patients' group}

A prospective study was approved by local research and ethics committee and a written informed consent was obtained from the subjects. Patients with CTEPH scheduled for isolated PEA on the 2nd Department of Surgery - Department of Cardiovascular Surgery, General Faculty Hospital in Prague were enrolled into study between January 2008 and March 2011. Respecting gender differences in hepcidin basal concentrations with significantly higher levels in men (Grebenchtchikov et al., 2009), only male patients were included into our study. Exclusion criteria were the combination of PEA with other surgical procedure (PEA with maze or PEA with coronary artery bypass grafting), postoperative bleeding, thromboembolic complication, local and systemic infection, defined according to guidelines of the Center for Disease Control and Prevention (Horan \& Gaynes, 2004).

\subsection{Anesthesia and surgical procedures}

30 minutes before skin incision, the first prophylactic dose of sultamicillin $1.5 \mathrm{~g}$ (Unasyn, Pfizer, Italy) was given. The same dose was repeated every 3 hours throughout the procedure and every 6 hours postoperatively until postoperative day 2 . A total intravenous anesthesia using combination of benzodiazepines, propofol, opioids and muscle relaxants routinely used in our institution for PEA was given to all study patients.

The standard approach for PEA was median sternotomy. Cardiopulmonary bypass (CPB) was established with cannulation of the ascending aorta and the inferior and superior vena cava. DHCA $\left(18-20^{\circ} \mathrm{C}\right)$ was used to ensure optimum operating conditions and facilitate accurate endarterectomty. Endarterectomy was started with dissection in right level of pulmonary artery and followed to the segmental branches. To achieve accurate visualization during peripheral dissection, repeated periods of DHCA limited to 20 minutes were performed with reestablishment of CPB between them. Arteriotomy on the main pulmonary artery was started on the left side and continued to the left branch. After completion of endarterectomy on the both sides, $\mathrm{CPB}$ was recommenced along with controlled rewarming. Weaning from $\mathrm{CPB}$ was started with pressure control ventilation with positive endexpiratory pressure, atrio-ventricular epicardial stimulation, stepwise increased filling of the right heart and reduction of pump flow together with low doses of norepinephrine Dobutamine (Dobutrex, Lily, Germany) was administered only if inotropic support was needed during or after weaning of $\mathrm{CPB}$. Before the end of $\mathrm{CPB}$, we used an ultra filtration for hemoconcentration. 


\subsection{Monitoring}

Radial and femoral artery cannulae, triple lumen central venous cannula, Swan-Ganz catheter, and single lumen jugular bulb catheter were inserted for continuous monitoring of hemodynamic parameters and jugular bulb blood saturation. Left atrial catheter was surgically placed for both measurement and norepinephrine administration.

\subsection{Blood sample collection}

Arterial blood samples were drawn from femoral artery catheter before operation, after sternotomy, after DHCA, after separation from CPB, then 12, 18, 24, 36, 48, 72, and $120 \mathrm{~h}$ after separation from CPB. For all measurements, $5-\mathrm{ml}$ of arterial blood was drawn into a vacutainer heparin tube and immediately centrifuged at $5000 \mathrm{rpm}$ for $15 \mathrm{~min}$. Plasma was stored at $-80^{\circ} \mathrm{C}$ until analysis.

\subsection{Hepcidin, prohepcidin and inflammatory parameters}

Plasma hepcidin and prohepcidin concentrations were measured by enzyme-linked immunoassays using a commercially available kits (DRG Diagnostics, Marburg, Germany) in duplicates - the analytical sensitivity of the assay for hepcidin analysis was $0.9 \mathrm{ng} / \mathrm{ml}$, intraassay coefficients of variation (CV) calculated by DRG Diagnostics was below $5 \%$, inter-assay precision was $11 \%(6,0 \mathrm{ng} / \mathrm{ml})$ and $10 \%(15,8 \mathrm{ng} / \mathrm{ml})$. Plasma levels of procalcitonin (PCT) were detected by Kryptor test (BRAHMS AG, Hennigsdorf, Germany) in duplicates. The sensitivity of the analytic method was $0.02 \mathrm{ng} / \mathrm{ml}$. Plasma concentrations of tumor necrosis factor (TNF)a, IL-6, IL-8 (ELISA, Immunotech, Paris, France), C-reactive protein (CRP) (Kryptor - TRACE technology, ultrasensitive analysis, BRAHMS AG, Hennigsdorf, Germany), $\mathrm{a}_{1}$-antitrypsin, and ceruloplasmin (nephelometry, BRAHMS AG, Hennigsdorf, Germany) were measured in duplicates, too. The intra- and inter-assay CV were below $5 \%$.

\subsection{Iron, ferritin and transferrin}

Plasma iron (colorimetric analysis, Pliva-Lachema a.s., Brno, Czech Republic), ferritin, and transferrin (immunoturbidimetry, Dialab Gmbh, Wr. Neudorf, Austria) were examined preoperatively and repeatedly within $120 \mathrm{~h}$ after the end of surgery.

\subsection{Hemodynamic parameters}

Mean pulmonary artery pressure (MPAP), cardiac index (CI), pulmonary vascular resistance (PVR), and ejection fraction (EF) were followed. The time of norepinephrine support was recorded in all patients.

\subsection{Statistical analysis}

Statistical analysis was carried out using SPSS software (version 12.0) for Windows (SPSS, Chicago, USA). The normal distribution of all data was examined using the KolmogorovSmirnov normality test to determine subsequent use of tests for statistical comparison. As variables were not normally distributed, the data were reported as medians and interquartile range. Bonferroni correction (multiple-comparison correction) was used to analyze simultaneous measurement at different time points. The Pearson's correlation coefficient and the Spearman's rank correlation evaluated correlation between the indicators. For all the tests, $\mathrm{p}<0.05$ was defined as statistically significant. 


\section{Results}

\subsection{Patients}

34 patients were enrolled during the 39 months of the trial (Tab. 1). All patients underwent satisfactory clearance of intra-arterial obstruction, and there were no intra-operative deaths. No patients required allogenic blood transfusion. Mean duration of CPB was $334.2 \pm 44.6$ min.; mean duration of crossclamping time was $121.0 \pm 20.5 \mathrm{~min}$. and circulatory arrest time $41.9 \pm 7.1 \mathrm{~min}$. Extracorporeal circulation (ECC) time was $330.9 \pm 54.4 \mathrm{~min}$; duration of mechanical ventilation was $51.9 \pm 30.6 \mathrm{~h}$. There was considerable improvement in hemodynamic variables. PEA significantly decreased MPAP (from $53.4 \pm 8.66$ to $25.1 \pm 7.04$ $\mathrm{mm} \mathrm{Hg}, \mathrm{p}<0.001$ ) as well as pulmonary vascular resistance (from $1095.4 \pm 325.3$ to $209.7 \pm$ 94.1 dynes.s.cm ${ }^{-5}, \mathrm{p}<0.001$ ). CI increased within first $24 \mathrm{~h}$ after surgery (from $1.90 \pm 0.37$ to $\left.3.04 \pm 0.491 . \mathrm{min}^{-1} \mathrm{~m}^{-2}, \mathrm{p}<0.001\right)$.

\begin{tabular}{|l|l|}
\hline Number of patients (males) & 34 \\
Age (yr.) & $51.4(9.6)$ \\
Preoperative New York Heart Association classification & $3.4(0.4)$ \\
Mean pulmonary artery pressure (mm Hg) & $54.2(6.8)$ \\
\hline
\end{tabular}

Variables are absolute number or mean (standard deviation).

Table 1. Pre-operative data

\subsection{Prohepcidin}

The time course of prohepcidin in perioperative period is shown in Fig. 1. Cardiac surgery with $\mathrm{CPB}$ induced a $49 \%$ fall in plasma prohepcidin. Prohepcidin decreased from preoperative level $94.9 \mathrm{ng} / \mathrm{ml}(84.5$ - 104.9) (median and interquartile range) to minimum 48.5 $\mathrm{ng} / \mathrm{ml}(38.2$ - 56.8). The initial decline was revealed after DHCA, and minimal concentrations

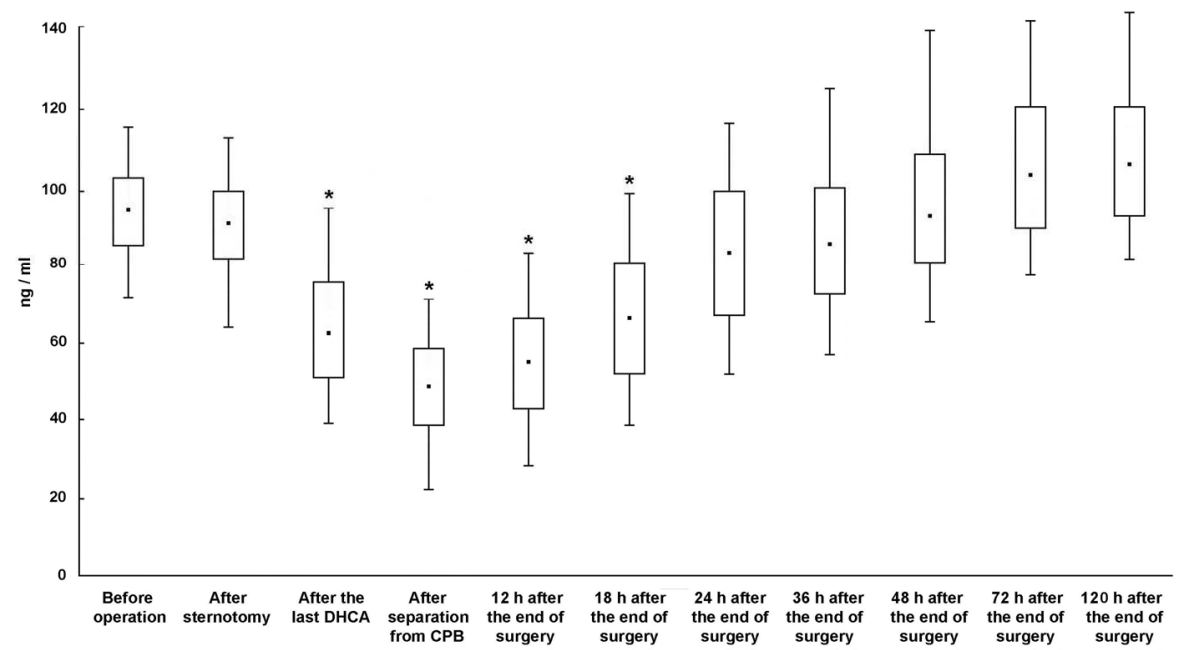

Box and whisker plot depicting the median values, interquartile range and full range.

*... Statistically significant differences to preoperative values, $\mathrm{p}<0.05$.

The same arrangement used for Fig $1-5$.

Fig. 1. Prohepcidin plasma concentrations in perioperative period. 
were detected after separation from CPB ( $p<0.001$ in relation to preoperative levels) after which the levels started rise. Concentrations returned to initial levels within $24-48 \mathrm{~h}$ after the separation from CPB. The following increase was found in samples at $72 \mathrm{~h}$ and $120 \mathrm{~h}$, but without a statistical significance to preoperative levels on $\mathrm{p}<0.05$.

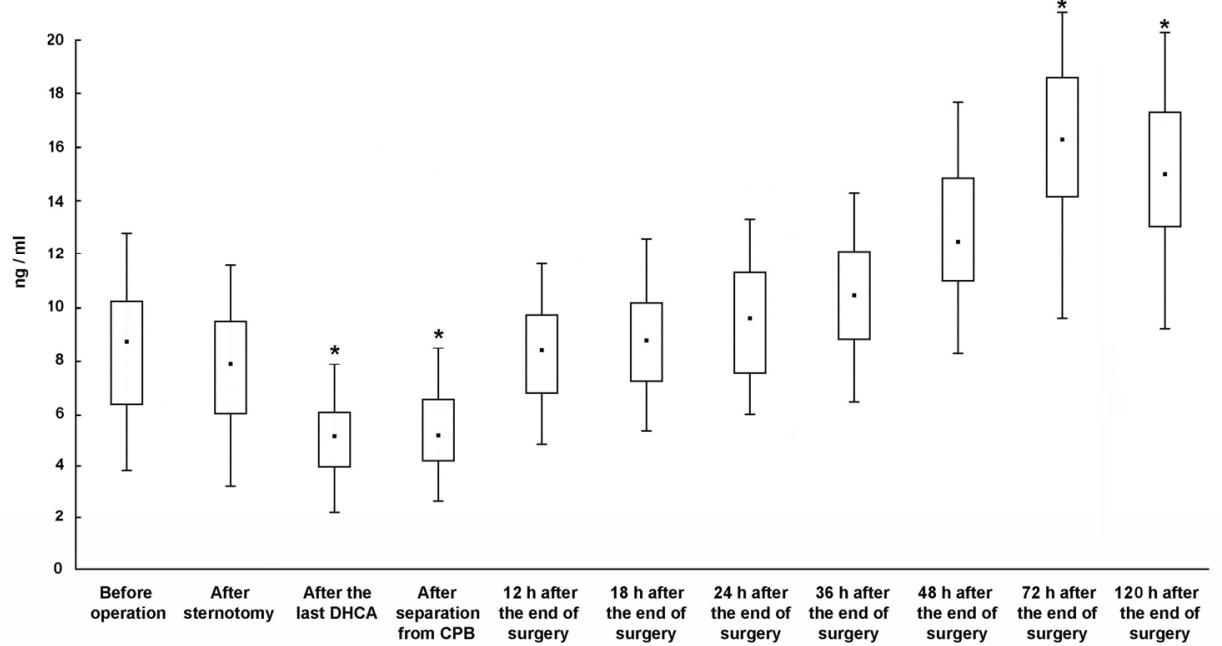

Fig. 2. Hepcidin plasma concentrations in perioperative period (median values, interquartile range and full range)

\subsection{Hepcidin}

Post-surgical course of plasma hepcidin was associated with a transient initial decline from preoperative level $8.6 \mathrm{ng} / \mathrm{ml}(6.4-10.2)$ and subsequent significant elevation above preoperative levels (Fig. 2). Minimal hepcidin concentrations were found in blood samples collected after the last DHCA. Initial decline of hepcidin appeared to correlate with the decreased hematocrit due to hemodilution on CPB $(\mathrm{r}=0.86, \mathrm{p}=0.002)$. After it, hepcidin increased to maximum $16.2 \mathrm{ng} / \mathrm{ml}(13.9$ - 18.9) measured $72 \mathrm{~h}$ after the end of surgery (e.g., separation from $\mathrm{CPB}$ ). In following period, the levels started declining but were still higher than pre-operatively until $120 \mathrm{~h}$ after the end of surgery.

\subsection{Cytokines and acute-phase proteins}

As expected, all inflammatory cytokines, PCT and acute-phase proteins increased after surgery. An uncomplicated course after PEA was associated with a transient initial decline of PCT and subsequent elevation. Minimal PCT concentrations were found in blood samples collected after the last DHCA (Fig. 3). Initial decrease of PCT appeared to correlate with the decreased hematocrit due to hemodilution on CPB $(\mathrm{r}=0.78, \mathrm{p}<0.01)$. PCT increased postoperatively from $0.22 \mathrm{ng} / \mathrm{ml}(0.15-0.31)$ reaching a peak level $24 \mathrm{~h}$ after the end of surgery $(2.05 \mathrm{ng} / \mathrm{ml}, 1.68-2.52)$.

All measured inflammatory cytokines increased after surgery. TNFa rose from $18 \mathrm{ng} / 1$ (10 47) to maximum $216 \mathrm{ng} / \mathrm{l}(136-415)$ in blood sample collected $12 \mathrm{~h}$ after separation from CPB. IL-6 rise was maximal 12 hours postoperatively from $26.2 \mathrm{ng} / 1(21.0-36.7)$ to 544.2 ng/1 (411.0 - 641.2) with following decline (Fig. 4). IL-8 with preoperative levels $42.4 \mathrm{ng} / \mathrm{l}$ 
(22.3 - 82.0) culminated later, $18 \mathrm{~h}$ after separation from CPB (446.0 ng/1, 274.2 - 658.1) with following decline.

Three tested acute-phase proteins showed prolonged elevation post-surgery. CRP increased to a peak level $48 \mathrm{~h}$ after the end of surgery (53 mg/l, $40-72)$ (Fig. 5). The same dynamics was found in $\mathrm{a}_{1}$-antitrypsin. Ceruloplasmin increase was delayed in relation to other tested acute-phase proteins reaching maximal levels $72 \mathrm{~h}$ after separation from CPB.

\subsection{Relations among hepcidin, prohepcidin and inflammatory markers}

Postoperative peak values of PCT and IL-6 correlated closely $(\mathrm{r}=0.81, \mathrm{p}<0.01)$, as well as peak values of PCT and CRP $(r=0.72, p<0.01)$ and peak values of PCT and TNFa $(r=0.62$, $\mathrm{p}<0.05)$. Correlation between PCT and other parameters wasn't significant on $p<0.05$. Maximum postoperative concentrations of IL-6 correlated with maximum IL-8 levels $(\mathrm{r}=$ $0.81, \mathrm{p}<0.01)$.

Plasma hepcidin and prohepcidin concentrations didn't correlate preoperatively. Correlation between maximum postoperative hepcidin concentrations $72 \mathrm{~h}$ after the end of surgery and prohepcidin concentrations at the same samples $(p=0.056)$ didn't achieve statistical significance.

No significant correlation was revealed between plasma hepcidin and IL-6 concentrations preoperatively as well as between hepcidin and other tested inflammatory markers, hemodynamic values, plasma iron, transferrin and ferritin before the start of surgery. Similarly plasma prohepcidin did not correlate with any tested inflammatory parameter, plasma iron, transferrin or ferritin preoperatively.

Maximum post-operative concentrations of hepcidin measured $72 \mathrm{~h}$ after a separation from $\mathrm{CPB}$ correlated with maximum IL-6 levels $12 \mathrm{~h}$ after the end of surgery $(\mathrm{r}=0.714, \mathrm{p}=0.021)$ as well as with IL-6 levels measured $18 \mathrm{~h}(\mathrm{r}=0.644, \mathrm{p}=0.032)$ and $24 \mathrm{~h}$ after the end of surgery $(r=0.614 . p=0.042)$. Similarly hepcidin and CRP concentrations correlated significantly $72 \mathrm{~h}$ after the end of surgery $(\mathrm{p}=0.044)$. No other tested inflammatory parameter correlated with hepcidin post-surgery on $\mathrm{p}<0.05$.

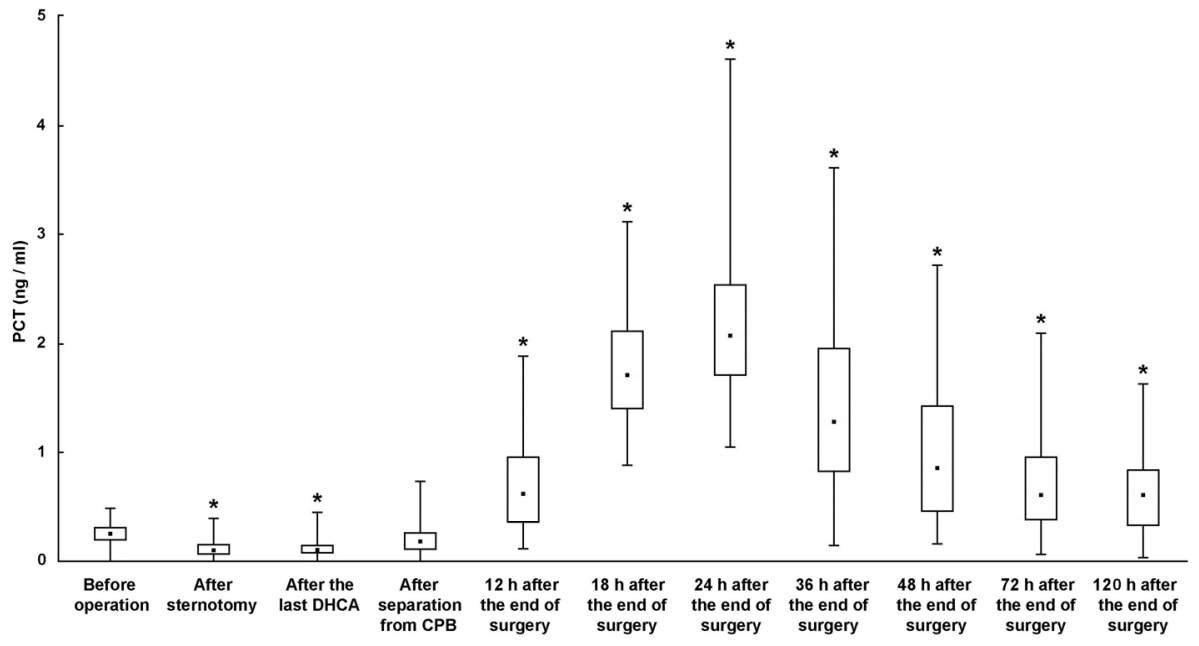

Fig. 3. PCT plasma concentrations in perioperative period (median values, interquartile range and full range) 


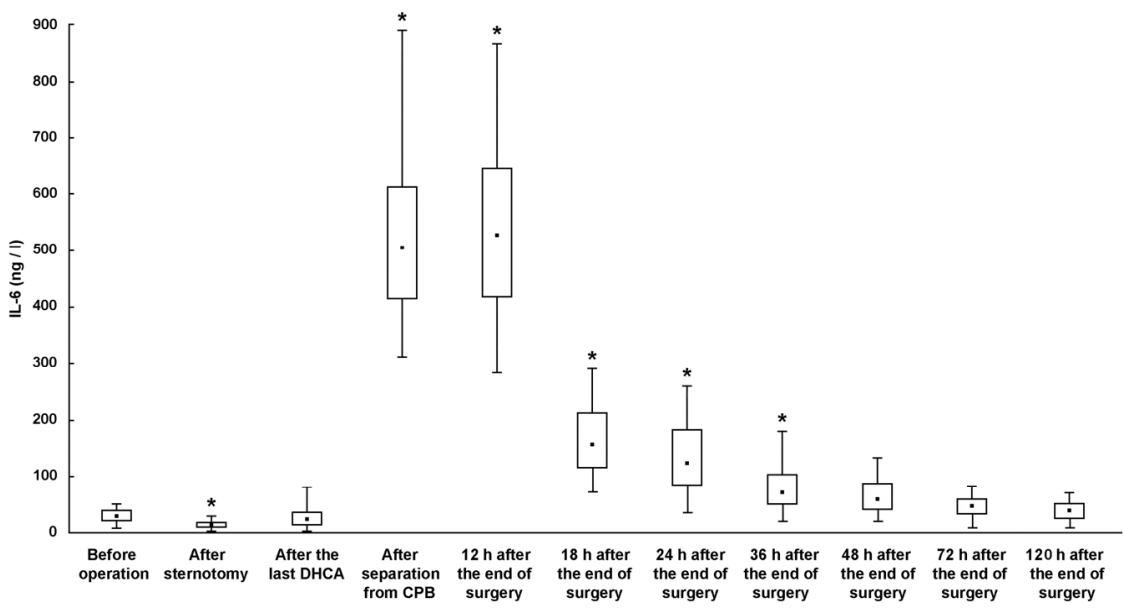

Fig. 4. IL-6 plasma concentrations in perioperative period (median values, interquartile range and full range)

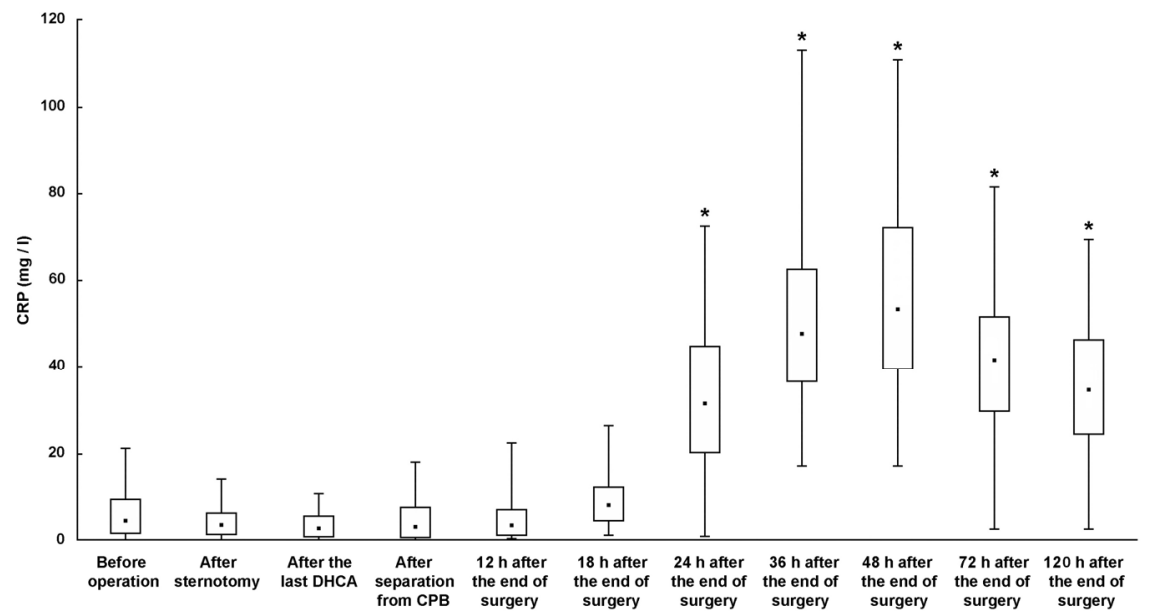

Fig. 5. CRP plasma concentrations in perioperative period (median values, interquartile range and full range)

\subsection{Relations among hepcidin, prohepcidin and hemodynamic parameters}

Minimal perioperative prohepcidin concentrations correlated inversely with ECC time $(\mathrm{r}=-0.84, \mathrm{p}<0.01)$. When evaluating patients with a quick normalization of prohepcidin into preoperative range within $24 \mathrm{~h}$ after separation from CPB (Subgroup 1, $\mathrm{n}=16$ ), higher peak plasma levels of IL-6 (620.9 ng/1, 484.2 - 782.0) were revealed in this subgroup compared with patients with delayed prohepcidin normalization (Subgroup 2, n = 18), their IL-6 peak levels were $438.2 \mathrm{ng} / 1$ (370.1 - 512.7), $\mathrm{p}<0.05$ between subgroups. Similarly, IL-8 peak postoperative concentrations were higher in Subgroup 1 in relation to Subgroup 2, but the differences were not significant on $\mathrm{p}<0.05$. 
Hepcidin maximum concentrations correlated positively with ECC time $(p=0.049)$. Hepcidin evolution post-surgery was not related to CI, MPAP, PVR and EF on $p<0,05$. Among inflammatory markers, IL-6 plasma concentrations correlated inversely with CI at the time of separation from CPB $(\mathrm{k}=-0.644, \mathrm{p}=0.029)$. Similarly IL-8 concentrations correlated significantly with $\mathrm{CI}$ at the same time $(\mathrm{k}=-0.636, \mathrm{p}=0.017)$.

\subsection{Iron, ferritin and transferrin}

$48 \mathrm{~h}$ postoperatively, there was a significant decrease in serum iron concentration (Table 2). Plasma ferritin levels $(44.6 \mu \mathrm{g} / \mathrm{l}, 19.4-72.9$ preoperatively) increased slightly at $36 \mathrm{~h}$ after separation from CPB (139.2 $\mu \mathrm{g} / 1,44.9$ - 172.9) and stayed elevated without significant dynamics until the end of tested period. Plasma ferritin did not significantly correlate with prohepcidin and hepcidin or any other tested inflammatory parameter. Multifactorial analysis did not reveal significant correlation between hepcidin and iron, resp. prohepcidin and iron within a 120-hour time frame after a separation from CPB. Similarly, both parameters did not correlate with plasma transferrin, hemoglobin concentration, alanine aminotransferase or aspartate aminotransferase activities post-surgery. No correlation was found between plasma hepcidin or prohepcidin levels and creatinine levels in postoperative period.

\begin{tabular}{|l|l|l|l|}
\hline Time & Iron $(\mu \mathrm{mol} / \mathrm{l})$ & Ferritin $(\mu \mathrm{g} / \mathrm{l})$ & Transferrin $(\mathrm{g} / \mathrm{l})$ \\
\hline Before sternotomy & $21.3(13.2-27.7)$ & $44.6(19.4-72.9)$ & $2.6(1.8-3.2)$ \\
$12 \mathrm{~h}$ after separation from CPB & $13.4 *(7.9-22.3)$ & $38.9 *(20.4-69.0)$ & $1.6 *(1.0-2.2)$ \\
$18 \mathrm{~h}$ after separation from CPB & $13.7 *(7.1-18.5)$ & $59.9(28.4-88.2)$ & $2.0(1.4-2.6)$ \\
$24 \mathrm{~h}$ after separation from CPB & $15.0(9.6-20.7)$ & $112.1(69.4-164.3)$ & $1.8(1.3-2.3)$ \\
$36 \mathrm{~h}$ after separation from CPB & $14.1(9.8-19.8)$ & $139.2 *(44.9-172.9)$ & $1.6 *(1.0-2.1)$ \\
$48 \mathrm{~h}$ after separation from CPB & $12.7 *(7.7-16.1)$ & $128.0 *(74.7-188.3)$ & $1.6 *(0.9-2.0)$ \\
$72 \mathrm{~h}$ after separation from CPB & $13.0 *(7.0-18.8)$ & $122.4 *(71.2-152.1)$ & $2.1(1.7-2.8)$ \\
$120 \mathrm{~h}$ after separation from CPB & $12.4 *(7.4-19.1)$ & $116.7 *(79.0-164.2)$ & $2.3(1.9-3.1)$ \\
\hline
\end{tabular}

Variables are medians (interquartile range).

*... Statistically significant differences to preoperative values on $\mathrm{p}<0,05$.

Table 2. Plasma iron, ferritin and transferrin in perioperative period

\section{Discussion}

This study has demonstrated the large cardiac surgery as an inductor of a deep transient decrease of prohepcidin plasma concentrations. Minimal postoperative prohepcidin levels were related to ECC time and did not correlate with IL- 6 or other tested inflammatory parameters. Nevertheless higher IL-6 concentrations advanced prohepcidin normalization after its initial decline. Postoperative changes of plasma iron or transferrin concentrations and hemoglobin concentration did not correlate with plasma prohepcidin levels. Hepcidin 
concentrations increased post-operatively reaching a maximum $72 \mathrm{~h}$ after the separation from $\mathrm{CPB}$. In a homogenous group of uncomplicated cardiosurgical patients, significant correlation between hepcidin and IL-6 concentrations post-surgery was observed. Our results are in conformity with a recent study by Hoppe et al. (2009). On a limited number of patients undergoing heart surgery, authors found significant alterations in both serum hepcidin and serum prohepcidin. Serum prohepcidin decreased after $48 \mathrm{~h}$ compared with preoperative values, whereas serum hepcidin increased within a 144-hour time frame.

The human hepcidin gene, located on chromosome 19q13.1, encodes a precursor protein, preprohepcidin of 84 aa. Preprohepcidin undergoes enzymatic cleavage, resulting in the export of a 64 -aa prohepcidin peptide into the endoplasmic reticulum lumen. Next, the 39-aa proregion peptide is probably posttranslationally removed resulting in mature bioactive hepcidin25 (25-aa form). In human urine, hepcidin-22 and hepcidin-20 were identified, which are Nterminally truncated isoforms of hepcidin-25 (Park et al., 2001). Kemna et al. (2008) results support the hypothesis that the 22-aa peptide is a urinary degradation product of hepcidin-25. An active hepcidin is a 8 cysteine-containing peptide with a distorted $\beta$-sheet which is stabilized by four disulfide bridges between the two anti-parallel strands (Hunter et al., 2002). The high cysteine content of the molecule is highly conserved among other species. Structurefunction in vivo (mice) and in vitro studies on synthetic hepcidin have shown that the iron regulating bioactivity is almost exclusively due to the 25 aa peptide, suggesting that the five $\mathrm{N}$ terminal amino acids are essential for this activity. In vitro experiments have shown that especially human hepcidin-20 exerts anti-bacterial and anti-fungal activity in a concentration range 10-fold higher than that measured in healthy individuals (Krause et al., 2000; Park et al., 2001). Nevertheless modeling of a best-fit 3D structure of hepcidin with iron demonstrated significant differences from the previously reported synthetic hepcidin model (Hunter et al., 2002). These new findings suggest a conformational polymorphism for hepcidin as a regulatory mechanism for iron uptake as part of its role as regulator of iron homeostasis.

Hepcidin is produced and secreted predominantly by hepatocytes, circulates in the bloodstream, and is excreted by the kidneys. Expression as studied on mRNA level is also detectable in other tissues (heart, kidney, adipose tissue, pancreas and hematopoietic cells), although the biological relevance of extra-hepatic hepcidin is not well defined yet (Vokurka et al., 2009). Hepcidin expression is regulated in response to iron, erythropoietic demand, hypoxia, and inflammatory signals. Inflammation is a potent inducer of hepcidin expression. Hepcidin was demonstrated to be up-regulated by a set of inflammatory cytokines. The synthesis is up-regulated in intact animals by the injection of lipopolysaccharide (endotoxin) and IL-6 although a direct stimulating effect of other cytokines as IL-1 $\alpha$, and IL-1 $\beta$ was confirmed in in vitro studies (Lee et al., 2005). Anemia and hypoxia inhibit hepcidin expression, thus increasing iron availability for erythropoiesis. Probably the activity of erythropoiesis rather than simple anemia was postulated later as an important regulatory factor (Vokurka et al., 2006; Weiss \& Goodnough, 2005). Recent studies brought new data about molecular pathways of the regulation of hepcidin gene through these different stimuli (reviewed by Kemna et al., 2008; Zhang \& Enns, 2009).

In vitro observations and first animal and clinical studies including our results support a submission of hepcidin into a group of acute-phase proteins (Young et al., 2009). Acute-phase proteins is the generic name of approximately 30 different biochemically and functionally unrelated proteins. These proteins are secreted by hepatocytes and their plasma levels are either increased (positive reactants) or reduced (negative acute-phase reactants) after the onset of a systemic inflammatory reaction (Baumann, 1988). Cell types other than hepatocytes are 
known to produce acute-phase proteins in a limited amount. Most of acute-phase proteins are glycoproteins (with exception of CRP and serum amyloid A). Actually about 20 cytokines are known to stimulate acute-phase protein synthesis in liver. The major inducers are IL-6, IL-1 $\beta$, and TNFa but an essential role of IL-6 in this action is out of doubt (Gabay \& Kushner, 1999). Considering a dominant regulation by IL-6, hepcidin was classified as a type II acute-phase protein. Type I acute-phase proteins (CRP, serum amyloid A, a1-acid glycoprotein and other) are those that require the synergistic action of IL- 6 and IL- $1 \beta$ for maximum synthesis. Type II acute-phase proteins are those that require IL-6 only for maximal induction. Examples of type II proteins are fibrinogen chains, haptoglobin, and a2-macroglobulin. Expression of genes encoding type II acute-phase proteins is suppressed rather than being enhanced frequently by IL-1 $\beta$ (Ramadori et al., 1999). Additive, synergistic, co-operative, and antagonistic effects between cytokines and other mediator substances influencing the expression of acute phase proteins do occur and have been observed in almost all combinations.

There is a well-characterized mechanism of direct transcriptional activation of hepcidin expression by IL-6 binding to its receptor complex containing gp130 to activate janus kinase (JAK) and activator of transcription STAT3, which binds to a conserved DNA element in the proximal hepcidin promoter (Nemeth et al., 2003 and 2004; Pietrangelo et al., 2007; Truksa et al., 2007, Verga Falzacappa et al., 2007, Wrighting \& Andrews, 2006). Other proinflammatory cytokines, such as IL-1 $\beta$, may also play a role in hepcidin induction (Lee et al., 2005). A second mode of hepcidin regulation depends upon signaling through the bone morphogenetic protein/Smad (BMP/Smad) pathway. Babitt et al. (2007) showed that mice with a deletion in the Smad4 gene were unable to synthesize hepcidin in response to inflammatory stimuli or to iron load. In means that induction by IL-6 appears to require an intact BMP/Smad signaling pathway. Hepcidin is also produced in monocytes/macrophages, and is induced in these cells by LPS and certain bacterial pathogens through Toll-like receptors and possibly also the IL-6/STAT3 pathway (Liu et al., 2005).

The dynamic of hepcidin precursor - prohepcidin was different from hepcidin and all tested inflammatory markers including PCT, cytokines and acute-phase proteins. Prohepcidin decreased post-operatively. The decrease of prohepcidin after a heart surgery was firstly documented by Hoppe et al. (2009). However there are some controversies between clinical findings and experimental studies. In a recent experimental lipopolysaccharide model, the investigators did not observe any change in serum prohepcidin during a shorter time frame of $22 \mathrm{~h}$, although there was a tendency toward a decrease at the final observation (Kemta et al., 2005). There is a possibility that serum prohepcidin is a biological nonfunctional precursor of the active hepcidin, as was postulated by Taes et al. (2004) or Brookes et al. (2005). It has been demonstrated by Rivera et al. (2005) that the truncated 25-aa form of hepcidin exercises the hypoferremia effect. Furthermore, the same study assessed the relation between iron absorption and prohepcidin concentrations in healthy women and it did not see any correlation, Iron absorption by healthy women is not associated with either serum or urinary prohepcidin. Thus, a Hoppe's interpretation of the present serum prohepcidin data showing a decrease following surgery is that serum prohepcidin (as insulin and proteases) is synthesized as an inactive precursor that is proteolytically trimmed to be activated (Hoppe et al., 2009).

Technical problems complicated routine measurements of plasma hepcidin until 2009 (Piperno et al., 2009). Substantial clinical results come from the measurement of prohepcidin but its relation to hepcidin remains unclear (Frazer \& Anderson, 2009). Hepcidin was measured in serum or urine mainly by the method developed by Ganz (2008) and by 
various modifications of mass spectrometry (Swinkels et al., 2008). Recent methods used for hepcidin measurement comprise mass spectrometry (SELDI-TOF MS, MALDI-TOF MS, LCMS/MS, IC-TOF-MS) and immunochemical assays (competitive ELISA or RIA). Mass spectrometry-based methods might be superior in detecting bioactive hepcidin- 25 and distinguishing other isoforms. This may be valuable mainly in situations with variable presence of hepcidin isoforms like in chronic kidney disease (Kroot et al., 2009; Kroot et al., 2010).

The initial decrease of hepcidin and inflammatory cytokines was explained by hemodilution. The effect of hemodilution and hemofiltration on cytokine and acute phase protein concentrations during PEA was well described in our previous study (Maruna et al., 2008) and cleared after correction of cytokine concentrations to hematocrit. Other limitations of this study include possibility of hemolysis impacting the study findings. When using the CPB pump in cardiosurgical procedures taking several hours, there is a degree of mechanical hemolysis that can affect hematological biomarkers (Hoppe et al., 2009).

\section{Conclusion}

Our study showed prohepcidin as a negative acute phase reactant with a strong initial decrease after PEA. On the other hand, hepcidin increased after uncomplicated cardiac surgery and this finding is in conformity with recent experimental studies defining hepcidin as a type II acute-phase protein. Relations between IL-6 levels and duration of prohepcidin disturbance as well as between IL-6 and hepcidin post-surgery course were revealed in our study. It remains to be determined whether the initial decrease of prohepcidin documented in our study is due to proteolytic trimming of serum prohepcidin or there are another factors restraining prohepcidin elevation or inhibiting its production.

\section{Acknowledgement}

The study was supported with a grant MSM0021620819 of the Ministry of Education, Czech Republic.

\section{Abbreviations}

BMP Bone morphogenetic protein

CPB Cardio-pulmonary bypass

CRP C-reactive protein

CTEPH Chronic thromboembolic pulmonary hypertension

CV Coefficients of variation

DHCA Deep hypothermic circulatory arrest

ECC Extracorporeal circulation

EF Ejection fraction

IC-TOF-MS Immunocapture time-of-flight mass-spectrometry

IL Interleukin

LC-MS/MS Liquid chromatography tandem-MS techniques

MALDI-TOF MS Matrix assisted laser desorption/ionization time-of-flight mass spectrometry

MPAP Mean pulmonary artery pressure

PCT Procalcitonin

PEA Pulmonary endarterectomy 
PVR Pulmonary vascular resistance

SELDI-TOF MS Surface enhanced laser desorption/ionization time-of-flight mass

spectrometry

SPSS Statistical package for social sciences

STAT 3 Signal transducer and activator of transcription 3

TNFa Tumor necrosis factor- $\alpha$

\section{References}

Babitt, J. L.; Huang F. W.; Xia, Y.; Sidis, Y.; Andrews, N. C. \& Lin, H. Y. (2007). Modulation of bone morphogenetic protein signaling in vivo regulates systemic iron balance. J Clin Invest, Vol. 117, pp. 1933-1939

Baumann, H. (1988). The electrophoretic analysis of acute phase plasma proteins. Methods in Enzymology, Vol. 163, pp. 566-594

Brookes, M. J.; Sharma, N. K.; Tselepis, C. \& Iqbal, T. H. (2005). Serum pro-hepcidin: measuring active hepcidin or a non-functional precursor? Gut, Vol. 54, pp. 169-170.

De Domenico, I.; Zhang, T. Y.; Koening, C. L.; Branch, R. W.; London, N.; Lo, E.; Daynes, R. A.; Kushner, J. P.; Li, D.; Ward, D. M. \& Kaplan, J. (2010). Hepcidin mediates transcriptional changes that modulate acute cytokine-induced inflammatory responses in mice. J Clin Invest, Vol. 120, pp. 2395-2405

Frazer, D. M. \& Anderson, D. J. (2009). Hepcidin compared with prohepcidin. Am J Clin Nutr, Vol. 89, pp. 475-476

Gabay, C. \& Kushner, I. (1999). Acute-phase proteins and other systemic responses to inflammation. N Engl J Med, Vol. 340, pp. 448-454

Ganz, T. (2006). Hepcidin and its role in regulating systemic iron metabolism. Hematology Am Soc Hematol Educ Program, pp. 29-35

Ganz, T. (2008). Immunoassay for human serum hepcidin. Blood, Vol. 112, pp. 4292-4297

Ganz, T. \& Nemeth, E. (2009). Iron sequestration and anemia of inflammation. Semin Hematol, Vol. 46, pp. 387-393

Grebenchtchikov, N.; Geurts-Moespot, A. J.; Kroot, J. J. C.; den Heijer, M.; Tjalsma, H.; Swinkels, D. W. \& Sweep, F. G. J. (2009). High-sensitive radioimmunoassay for human serum hepcidin. Brit J Haematol, Vol. 146, pp. 317-325

Hoppe, M.; Lönnerdal, B.; Hossain, B.; Olsson, S.; Nilsson, F.; Lundberg, P. A.; Rödjer, S. \& Hulthén, L. (2009). Hepcidin, interleukin-6 and hematological iron markers in males before and after heart surgery. Nutr Biochem, Vol. 20, pp. 11-16

Horan, T. C. \& Gaynes, R. P. (2004): Surveillance of nosocomial infections. Appendix A: CDC definitions of nosocomial infections. In Mayahall CG (3rd ed): Hospital Epidemiology and Infection Control. Lippincot Williams and Wilkins, Philadelphia, USA, pp. 1659-1702

Hunter, H. N.; Fulton, D. B.; Ganz, T. \& Vogel, H. J. (2002). The solution structure of human hepcidin, a peptide hormone with antimicrobial activity that is involved in iron uptake and hereditary hemochromatosis. J Biol Chem, Vol. 277, pp. 37597-37603

Kemna, E. H.; Kartikasari, A. E.; van Tits, L. J.; Pickkers, P.; Tjalsma, H.; Swinkels, D. W. (2008). Regulation of hepcidin: insights from biochemical analyses on human serum samples. Blood Cells Mol Dis, Vol. 40, pp. 339-346

Kemna, E. H.; Pickkers, P.; Nemeth, E.; van der Hoeven, H. \& Swinkels, D. (2005). Timecourse analysis of hepcidin, serum iron, and plasma cytokine levels in humans injected with LPS, Blood, Vol. 106, pp. 1864-1866 
Krause, A.; Nietz, S.; Magert, H. J.; Schultz, A.; Forssmann, W. G.; Schultz-Knappe, P. \& Adermann, K. (2000). LEAP-1, a novel highly disulfide-bonded human peptide, exhibits antimicrobial activity. FEBS Lett, Vol. 480, pp. 147-150

Krijt, J.; Fujikura, Y.; Šefc, L.; Vokurka, M.; Hlobeňová, T. \& Nečas, E. (2010). Hepcidin downregulation by repeated bleeding is not mediated by soluble hemojuvelin. Physiol Res, Vol. 59, pp. 53-59

Kroot, J. J.; Kemna, E. H.; Bansal, S. S.; Busbridge M.; Campostrini, N.; Girelli, D.; Hider, R. C.; Koliaraki, V.; Mamalaki, A.; Olbina, G.; Tomosugi, N.; Tselepis, C.; Ward, D. G.; Ganz, T.; Hendriks, J. C. \& Swinkels, D. W. (2009). Results of the first international round robin for the quantification of urinary and plasma hepcidin assays: need for standardization. Haematologica, Vol. 94, pp. 1748-1752

Kroot, J. J.; Laarakkers, C. M.; Geurts-Moespot, A. J.; Grebenchtchikov, N.; Pickkers, P.; van Ede, A. E.; Peters, H. P.; van Dongen-Lases, E.; Wetzels, J. F.; Sweep, F. C.; Tjalsma H. \& Swinkels, D. W. (2010). Immunochemical and mass-spectrometry-based serum hepcidin assays for iron metabolism disorders. Clin Chem, Vol. 56, pp. 1570-1579

Langer, F.; Schramm, R.; Bauer, M.; Tscholl, D.; Kunihara, T. \& Schafers, H. J. (2004). Cytokine response to pulmonary thromboendarterectomy. Chest, Vol. 126, pp. 135-141

Lee, P.; Peng, H.; Gelbart, T.; Wang, L. \& Beutler, E. (2005). Regulation of hepcidin transcription by interleukin-1 and interleukin-6. Proc Natl Acad Sci USA, Vol. 102, pp. 1906-1910.

Lindner, J.; Maruna, P.; Kunstýř, J.; Jansa, P.; Gürlich, R.; Kubzová, K.; Zakharcenko, M. \& Linhart, A. (2009). Hemodynamic instability after pulmonary endarterectomy for chronic thromboembolic pulmonary hypertension correlates with cytokine network hyperstimulation. Eur Surg Res, Vol. 43, pp. 39-46

Liu, X. B.; Nguyen, N. B.; Marquess, K. D.; Yang, F. \& Haile, D. J. (2005). Regulation of hepcidin and ferroportin expression by lipopolysaccharide in splenic macrophages. Blood Cells Mol Dis, Vol. 35, pp. 47-56

Martínez Rosas, M. (2006). Cardiac remodeling and inflammation. Arch Cardiol Mex, Vol. 76, pp. S58-S66

Maruna, P.; Kunstýř, J; Plocová, K. M.; Mlejnský, F.; Hubáček, J. A.; Klein, A. A. \& Lindner, J. , (2011). Predictors of infection after pulmonary endarterectomy for thromboembolic pulmonary hypertension. Eur J Cardio-Thorac, Vol. 39, pp. 195-200

Maruna, P.; Lindner, J.; Kubzová, K. \& Kunstýř, J. (2008). Quantitative analysis of procalcitonin and cytokines after pulmonary endarterectomy. Prague Med Rep, Vol. 109, pp. 149-158

Maruna, P.; Lindner, J.; Kunstýř, J.; Plocová, K. \& Hubáček, J. (2009). Plasma prohepcidin as a negative acute phase reactant after large cardiac surgery with a deep hypothermic circulatory arrest. Physiol Res, Vol. 58, pp. 827-833

Nemeth, E.; Valore, E. V.; Territo, M.; Schiller, G.; Lichtenstein, A. \& Ganz, T. (2003). Hepcidin, a putative mediator of anemia of inflammation, is a type II acute phase protein. Blood, Vol. 101, pp. 2461-2463

Nemeth, E.; Rivera, S.; Gabayan, V.; Keller, C.; Taudorf, S.; Pedersen, B. K. \& Ganz, T. (2004). IL-6 mediates hypoferremia of inflammation by inducing the synthesis of the iron regulatory hormone hepcidin. J Clin Invest, Vol. 113, pp. 1271-1276

Nicolas, G.; Chauvet, C.; Viatte, L.; Danan, J. L.; Bigard, X.; Devaux, I.; Beaumont, C.; Kahn A. \& Vaulont, S. (2002). The gene encoding the iron regulatory peptide hepcidin is regulated by anemia, hypoxia, and inflammation. J Clin Invest, Vol. 110, pp. 10371044 
Papanikolaou, G.; Tzilianos, M.; Christakis, J. I.; Bogdanos, D.; Tsimirika, K.; MacFarlane, J.; Goldberg, Y. P.; Sakellaropoulos, N.; Ganz, T. \& Nemeth, E. (2005). Hepcidin in iron overload disorders. Blood, Vol. 105, pp. 4103-4105

Park, C. H.; Valore, E. V.; Waring, A. J. \& Ganz, T. (2001). Hepcidin, a urinary antimicrobial peptide synthesized in the liver. J Biol Chem, Vol. 276, pp. 7806-7810

Pietrangelo, A.; Dierssen, U.; Valli, L.; Garuti, C.; Rump, A.; Corradini, E.; Ernst, M.; Klein, C. \& Trautwein, C. (2007). STAT3 is required for IL-6-gp130-dependent activation of hepcidin in vivo. Gastroenterology, Vol. 132, pp. 294-300

Piperno, A.; Mariani, R.; Trombini, P. \& Girelli, D. (2009). Hepcidin modulation in human diseases: From research to clinic. World J Gastroenterol, Vol. 15, pp. 538-551

Ramadori, G. \& Christ, B. (1999). Cytokines and the hepatic acute-phase response. Seminars Liver Disease, Vol. 19, pp. 141-170

Rivera, R.; Nemeth, E.; Gabayan, V.; Lopez, M. A.; Farshidi, D. \& Ganz, T. (2005). Synthetic hepcidin causes rapid dose-dependent hypoferremia and is concentrated in ferroportin-containing organs, Blood, Vol. 106, pp. 2196-2199

Roscoe, A. \& Klein, A. (2008). Pulmonary endarterectomy. Curr Opin Anaesthesiol, Vol. 21, pp. $16-20$

Swinkels, D. W.; Girelli. D.; Laarakkers, C.; Kroot, J.; Campostrini, N.; Kemna, E. H. \& Tjalsma H. (2008). Advances in quantitative hepcidin measurements by time-offlight mass spectrometry. PLoS ONE, Vol. 3, p. e2706

Taes, Y. E.; Wuyts, B.; Boelaert J. R.; De Vriese, A. S. \& Delanghe, J. R. (2004). Prohepcidin accumulates in renal insufficiency, Clin Chem Lab Med, Vol. 42, pp. 387-389

Tselepis, C.; Ford, S. J.; McKie, A. T.; Vogel, W.; Zoller, H.; Simpson, R. J.; Daiz Castro, J.; Igbal, T. H. \& Ward, D. G. (2010). Characterization of the transition-metal-binding properties of hepcidin. Biochem J, Vol. 427, pp. 289-296

Truksa, J.; Peng, H.; Lee, P. \& Beutler, E. (2007). Different regulatory elements are required for response of hepcidin to interleukin- 6 and bone morphogenetic proteins 4 and 9. Br J Haematol, Vol. 139, 138-147

Vecchi, C.; Montosi G.; Zhang K.; Lamberti, I.; Duncan, S. A.; Kaurman, R. J.; Pietrangelo A. (2009). ER stress controls iron metabolism through induction of hepcidin. Science, Vol. 325, pp. 877-880

Verga Falzacappa, M. V.; Vujic Spasic, M.; Kessler, R.; Stolte, J.; Hentze, M. W. \& Muckenthaler, M. U. (2007). STAT3 mediates hepatic hepcidin expression and its inflammatory stimulation. Blood, Vol. 109, pp. 353-358

Vokurka, M.; Krijt, J.; Šulc, K. \& Nečas, E. (2006). Hepcidin mRNA levels in mouse liver respond to inhibition of erythropoiesis. Physiol Res, Vol. 55, pp. 667-674

Vokurka, M.; Lacinová, Z.; Křemen, J.; Kopecký, P.; Bláha, J.; Pelinková, K.; Haluzík, M. \& Nečas, E. (2010). Hepcidin expression in adipose tissue increases during cardiac surgery. Physiol Res, Vol. 59, pp. 393-400

Weiss, G. \& Goodnough, L. T. (2005). Anaemia of chronic disease. N Engl J Med, Vol. 352, pp. 1011-1023

Wrighting, D. M. \& Andrews, N. C. (2006). Interleukin-6 induces hepcidin expression through STAT3. Blood, Vol. 108, pp. 3204-3209

Young, B. \& Zaritsky, J. (2009). Hepcidin for clinicians. Clin J Am Soc Nephrol, Vol. 4, pp. 1384-1387.

Zhang, A. S. \& Enns, C. A. (2009). Molecular mechanisms of normal iron homeostasis. Hematology Am Soc Hematol Educ Program, pp. 207-214 


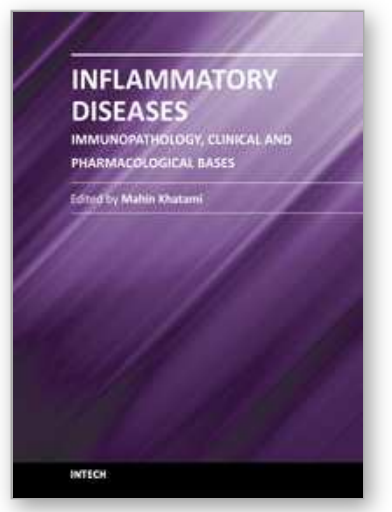

\author{
Inflammatory Diseases - Immunopathology, Clinical and \\ Pharmacological Bases \\ Edited by Dr Mahin Khatami
}

ISBN 978-953-307-911-0

Hard cover, 396 pages

Publisher InTech

Published online 10, February, 2012

Published in print edition February, 2012

This book is a collection of comprehensive reviews contributed by experts in the diverse fields of acute and chronic inflammatory diseases, with emphasis on current pharmacological and diagnostic options. Interested professionals are also encouraged to review the contributions made by experts in a second related book entitled "Inflammation, Chronic Diseases and Cancer"; it deals with immunobiology, clinical reviews, and perspectives of the mechanisms of immune inflammatory responses that are involved in alterations of immune dynamics during the genesis, progression and manifestation of a number of inflammatory diseases and cancers, as well as perspectives for diagnosis, and treatment or prevention of these disabling and potentially preventable diseases, particularly for the growing population of older adults around the globe.

\title{
How to reference
}

In order to correctly reference this scholarly work, feel free to copy and paste the following:

Pavel Maruna, Martin Vokurka and Jaroslav Lindner (2012). Prohepcidin and Hepcidin in Acute Phase Reaction Accompanying Large Cardiac Surgery, Inflammatory Diseases - Immunopathology, Clinical and Pharmacological Bases, Dr Mahin Khatami (Ed.), ISBN: 978-953-307-911-0, InTech, Available from: http://www.intechopen.com/books/inflammatory-diseases-immunopathology-clinical-and-pharmacologicalbases/prohepcidin-and-hepcidin-in-acute-phase-reaction-accompanying-large-cardiac-surgery

\section{INTECH}

open science | open minds

\author{
InTech Europe \\ University Campus STeP Ri \\ Slavka Krautzeka 83/A \\ 51000 Rijeka, Croatia \\ Phone: +385 (51) 770447 \\ Fax: +385 (51) 686166 \\ www.intechopen.com
}

\author{
InTech China \\ Unit 405, Office Block, Hotel Equatorial Shanghai \\ No.65, Yan An Road (West), Shanghai, 200040, China \\ 中国上海市延安西路65号上海国际贵都大饭店办公楼 405 单元 \\ Phone: +86-21-62489820 \\ Fax: +86-21-62489821
}


(C) 2012 The Author(s). Licensee IntechOpen. This is an open access article distributed under the terms of the Creative Commons Attribution 3.0 License, which permits unrestricted use, distribution, and reproduction in any medium, provided the original work is properly cited. 